\title{
Hukum Sebagai Kerangka Landasan Pembangunan
}

\author{
Oleh : Suparman Marzuki
}

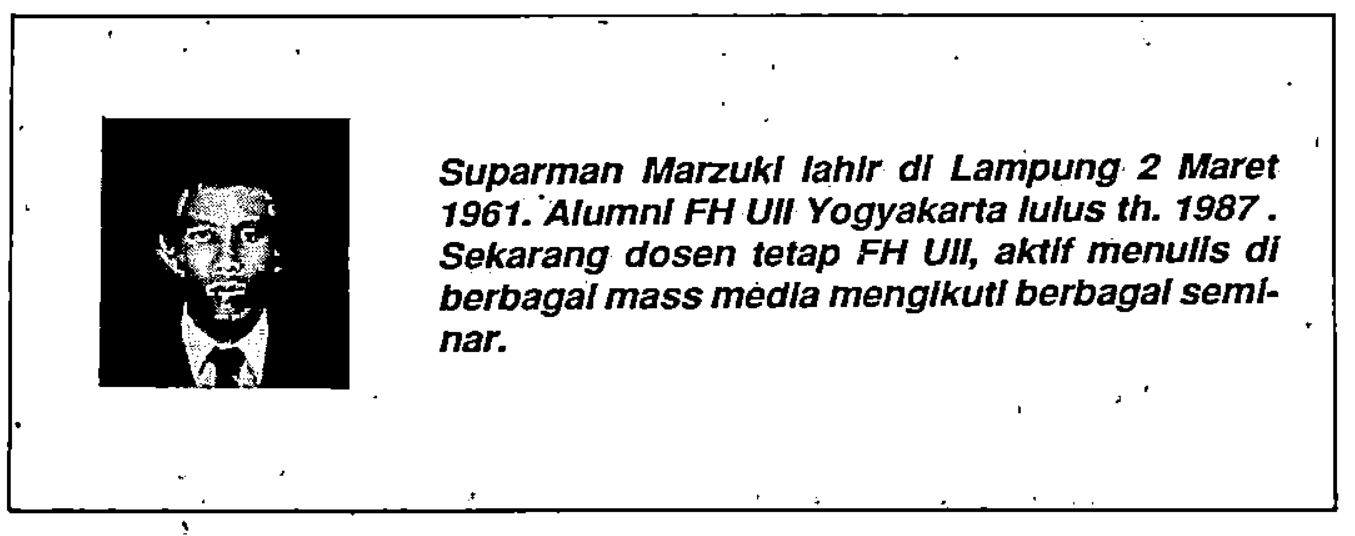

Dimensi sosial dari hukum kian hari kian bertambah luas seiring dengan makin menurunnya dominasi aliran legalisme hukum dan berkembangnya pemikiran fungsi instrumental hukum sebagai alat perubahan sosial (social engenering) serta kian cepatnya pertumbuhan pembangunan di semua bidang kehidupan yang memaksa pemerintah negara-negara berkembang menjadikan húkum sebagai kerangka landasan pembangunan.

Kuku-kuku hukum telah benar-benar mencekam ke dalam tubuh masyarakat. Dalam nada putus asa, bahkan ada orang yang menggerutu, jangan-jangan nanti berkedip pun diatur oleh hukum. Memang sejarah hukum mencatat suatu masa perjalanan yang sangat panjang, mulai hukum masih secara malu-malu menempati sudut-sudut kecil dalam kehidupan masyarakat sampai kini ia telah menjadi raja di raja dalam lalu lintas kehidupan masyarakat. Suka atau tidak, orang sekarang harus senantiasa memperhitungkan kehadiran hukum. .

Hukum telah menjadi sandaran dan . kerangka normatif kehidupan manusia dalam bermasyarakat, berbangsa dan bernegara.

Dalam sejarah hukum Indonesia, terutama sejak awal-awal Orde Baru kita melihat pulihnya peranan hukum dan pergeseran tema dari "hukum revolusi" pada demokrasi terpimpin menjadi hukum yang lebih serasi dengan cita-cita negara hukum. Pada periode ini menurut Daniel 
S. Lev. ditandai oleh kemerosotan hukum. formal sebagai kelanjutan meluasnya kegiatan politik dan sistem kepartaian berdasarkan ideologi yang menimbulkan sejumlah konflik (dalam Mulyana W. Kusumah. "Perspektif, Teori dan Kebijaksanaan Hukum", Rajawali, 1989. Hal . 19).

Dampak konflik yang merupakan ciri bekerjanya sistem politik tersebut terasa hampir pada semua bidang kehidupan. Proses hukum dengan segala dayagunanya untuk menyelesaikan sengketa turun seiring dengan menonjolnya proses politik serta segenap kerangka normatifnya. Ini terjadi karena memang semua sumber daya yang ada dimobilisasi oleh kubu yang saling bersaing pada waktu itu.

Tetapi sejak Orde Baru pertumbuhan pranata hukum, nilai dan prosedur, perundang-undangan serta birokrasi periegak hukum tidak hanya mencerminkan hukum sebagai kerangka landasan pembangunan, tetapi juga menjadi perangkat normatif penyangga struktur, ekonomi dan politik yang sedang berlansung.

Pendayagunaan hukum memang kian disadari arti pentingnya oleh perencana pembangunan, terutama pemerintahan negara-negara sedang berkembang. Seorang Ahli sosiologi hukum dari Princeton University, Lawrence Rosen, melihat adanya tiga dimensi penting pendayagunaan pranata-pranata hukum di dalam masyarakat sedang berkembang. Yaitu : (Dalam Mulyana W. Kusumah, "Peranan dan Pendayagunaan Hukum. dalam Pembangunan") Alumni. 1984. hal. 4.

1. Hukum sebagai pencerminan dan wahana bagi kónsep-konsep yang berbeda mengenai tertib dan kesejahteraan sosial yang berkaitan dengan pernyataan dan perlindungan kepentingan-kepentingan masyarakat.

2. Hukum dalam peranannya sebagai pranata otonom dapat pula merupakan pembatas kekuasaan sewenangwenang, sungguhpun pendayagunaan hukum tergantung pada kekuasaan lain di luamya.

3. Hukum dapat didayagunakan sebagai sarana untuk mendukung dan mendorong perubahan-perubahan sosial ekonomi.

Di Indonesia, perwujudan dimensi peranan hukum tersebut dilandasi oleh Pancasila dan UUD 1945 yang dijabarkan lebih lanjut pada setiap periode pembangunan di dalam Garis-Garis Besar Haluan Negara (GBHN) untuk setiap lima tahun sekali dengan pola operasional berupa Repelita. Dimensi peranan hukum dalam pembangunan dari satu Pelita ke Pelita selanjutnya merupakan rangkaian kelanjutan saja. Yang berbeda palingpaling penekanannya tergantung arah dan kecenderungan pembangunan sektorsektor penting lainnya terutama pembangunan ekonomi. Pendek kata pendayagunaan hukum selama dua dasawarsa pembangunan kita lebih ditempatkan sebagai sarana pembangunan, dimana pembangunan bersifat imperatif terhadap hukum dalam arti bahwa baik secara langsung maupun tidak, hukum diminta bantuannya untuk mengantarkan masyarakat ke arah pembangunan serta menampung akibat-akibat yang timbul dari padanya. Dalam Garis-Garis Besar Haluan Negara (GBHN) disebutkan beberapa point tentang fungsi dan arah pembangunan hukum nasional kita, terutama dalam rangka pelaksanaan 
pembangunan Pelita ke-V sekarang ini, yaitu antara lain :

a. Pembangunan hukum sebagai upaya untuk menegakkan keadilan, kebenaran dan ketertiban dalam negara hukum Indonesia yang berdasarkan Pancasila dan Undang-Undang Dasar 1945, diarahkan untuk meningkatkan kesadaran hukum, menjamin penegakan, pelayanan dan kepastian hukum, serta mewujudkan tata hukum nasional yang mengabdi pada kepentingan nasional:

b. Pembangunan hukum ditujukan untuk memantapkan dan mengamalkan pelaksanaan pembangunan dan hasilhasilnya, menciptakan kondisi yang lebih mantap sehingga setiap anggota masyarakat dapat menikmati iklim kepastian dan ketertiban hukum, lebih memberi dukungan dan pengarahan kepada upaya pembangunan untuk mencapai kemakmuran yang adil dan merata, serta menumbuhkan dan mengembangkan disiplin nasional dan rasä tanggung jawab sosial pada setiap anggota masyarakat. Disamping itu, hukum benarbẹnar harus menjadi pengayom masyarakat, memberi rasa aman dan tenteram, menciptakan lingkungan dan iklim yang mendorong kreatifitas dan partisipasi masyarakat dalam pembangunan serta mendukung stabilitas nasional yang sehat dan dinamis.

c. Dalam rangka pembangunan hukum perlu lebih ditingkatkan upaya pembaharuan hukum secara terarah dan terpadu antara lain kodifikasi dan unifikasi bidang-bidang hukum tertentu serta penyusunan perundang-undangan baru yang sangat dibutuhkan untuk dapat mendukung pembangunan di berbagai bidang sesuai dengan tuntutan pembangunan 'di berbagai bidang sesuai dengan tuntutan pembangunan, serta tingkat kesadaran hukum dan dinamika yang berkembang dalam masyarakat.

Arah dan strategi pendayagunaan hukum yang tertera dalam GBHN sekarang ini -- sekali lagi -- merupakan kelanjutan dari arah dan strategi pendayagunaan hukum periode pembangunan lima tàhun sebelumsebelumnya. Yang intinya lebih menekankan fungsi hukum sebagai instrumen pemeliharaan kelangsungan pembangunan dan hasil-hasilnya dan sekaligus pula untuk mencapai tujuan pembangunan yang telah digariskan.

Sejumlah perundang-undangan yang terbentuk selama pemerintahan Orde Baru seperti Undang-Undang Pokok Kekuasaan Kehakiman, Undang-Ündang Tentang Susunan dan Kedudukan MPR, DPR, dan DPRD, Undang-Undang mengenai Partai Politik dan Golongan Karya, dan lain sebagainya merupakan perangkat hukum yang dimaksudkan untuk mengatur, dan dengan demikian menertibkan kehidupan politik, sejalan dengan tujuan untuk menciptakan stabilitas sosial politik yang diperlukan untuk menunjang pelaksanaan pembangunan.

Kendati kecenderungan hukum kita lebih diarahkan pada fungsi instrumental hukum sebagai sarana ketertiban sosial, ekonomi dan politik, namun dimensi lain dari eksistensi hukum sebagai bagian dari proses pembangunan yang lebih luas pada hakekatnya tidak terelakkan. Karena seperti dikatakan Abdurrachman antara hukum di satu pihak dan pembangunan nasional di pihak lain pada hakekatnya terdapat suatu kaitan yang tak mungkin dilepaskan. Karena itu eksistensi hukum 
harus dilihat dalam dua dimensi. Di satu pihak hukum harus dilihat sebagai suatu bidang atau lapangan yang memerlukan pembinaan dan pembangunan sebagai salah . satu bagian dalam rangka pembangunan secara menyeluruh, yang sesuai dengan cita-cita bangsa Indonesia untuk menciptakan hukum nasional Indonesia guna menggantikan ketentuanketentuan hukum peninggalan kolonial yang sedikit banyak sudah tak mungkin dipertahankan lagi (Lihat Abdurahman, "Aneka. Masalah Hukum dan Pembangùnan di Indonesia", 1979, hal . 12).

Dari dimensi lain kita harus melihat fungsi hukum sebagai suatu alat atau sarana penting untuk menunjang kelangsungan pembangunan. Disini hukum dalam fungsinya sebagai "a tool of social engenering" bukan saja menjadi landasan bagi program pembangunan dalam artian bahwa keseluruhan proses pembangunan itu harus dilaksanakan di atas relnyá hukum, akan tetapi juga dari ketentuan-ketentuan hukum diharapkan. beberapa in-put dalam mempercepat proses pembangunan itu sendiri.

Lebih-lebih dalam menuju industriålisasi seperti sekarang ini dibutuhkan adảnya kerangka dasar tertentu yang memungkinkan usaha industrialisasi tidak sekedar mendirikan pabrik-pabrik di tengah-tengah masyarakat yang mayoritas masih menganggap mesin sebagai benda maksiat atau tidak sekedar membebaskan tanah rakyat untuk bangunan gedung, jalán, sarana umum lainnya atau bentukbentuk penegakan' hukùm represif lainya. Di sini dibutuhkan adanya suatu kerangka kehidupan sosial tertentu yang memungkinkan terlaksananya usaha industrialisasi tersebut. Ke dalam kerangka ini termasuk beberapa kegiatan bidang hukum yang mampu merespon tuntutantuntutan sosial yang berkembang serta mendorong perubahan sikap dan perilaku ke arah perubahan yang diinginkan.

Barangkali penting dikemukakan bentuk peranan hukum yang lebih terperinci, untuk melihat aspek-aspek fungsi hukum dalam dinamika pembangunan suatu bangsa, yaitu : (lihat Satjipto Rahardjo, "Hukum dan Masyarakat", Angkasa, 1980, Hal. 136).

1. Penciptaan lembaga-lembaga hukum baru yang melancarkan dan mendorong, pembangunan.

2. Mengamankan hasil-hasil yang diperoleh oleh kerja dan usaha. Sekalipun pembangunan itu menghendaki keleluasaan untuk melakukan perubahan-perubahan namun pada akhimya dikehendaki agar orang memperoleh kepastian tentang hasil pekerjaan atau usahanya. Taripa kepastian terhadap pengharapan ini tak dapat ditunggu adanya partisipasi yang - baik dari masyarakat terutama sektor swasta:

3. Pengembangan apa yang oleh Kenneth. L. Karst disebut; Keadilan untuk pembangunan yang pada intinya menghendaki agar masyarakat senantiasa ada di pihak: yang memikirkan pembangunan untuk kepentingan bagian terbesar dari rakyat. Untuk dapat mencapai tujuan ini maka pemerintah hendaknyạ dapat memanfaatkan saat-saat di mana peristiwa-peristiwa ini misalnya adalah :pendistribusian hak-hak atas tanah 
kepada para petani; pegawai negeri yang dipidana karena menerima suap; seorang tuan tanah telah dipaksa untuk mendirikan fasilitas pipa-pipa air yang memadai; seorang anak desa memperoleh bea siswa dan sebagainya.

4. Pemberian legitimasi terhadap perubahan-perubahan. Tujuan daripadanya adalah untuk membantu orang-orang melakukan pilihan-pilihan yang akan memberikan efek yang mendorong perubahan yang membangun.

5. Penggunaan hukum untuk melakukan perombakan-perombakan. Di sini kita melihat perubahan hukum dalam usaha pembaharuan sosial. Lembagalembaga lama yang menghambat pembangunan dirobohkan oleh hukum. Dalam pada itu perobahan ini akan menimbulkan gangguan pada sistem hukum yang ada dan ini menyebabkan bahwa usaha perombakan hukum ini juga menghendaki penciptaan lembaga hukum baru sebagai gantinya.

6. Peranan dalam penyelesaian perselisihan. Dalam peran ini kita akan melihat peran hukum yang benar-benar hukum (distinctively legal) : penyelesaian yang dilakukan berdasarkan prosedur yang telah dipersiapkan dalam rangka penyelesaian yang demikian itu. Peranan hukum di dalam katagori menunjang pembangunan, oleh karena pembangunan sebagai perubahan melibatkan banyak kegiatan-kegiatan. Kegiatan mengandung di dalam dirinya risiko terhadap kepentingankepentingan yang ada, khususnya risiko yang bersifat mencelakakannya.
Maka orang-orang yang mengalami gangguan tersebut akan mencari jalan untuk dapat memulihkan hak-hak dan kepentingannya. Apabila pembangunan diterima sebagai suatu rangkaian perubahan-perubahan, maka pembangunan dengan demikian membuka jalan bagi terjadinya persengketaan secara terus menerus yang tentunya mengundang penyelesaian demi ketertiban di dalam masyarakat. Di sini kadar persoalannya tidak hanya dapat ditinjau dari segi penyelesaian sengketa saja, melainkan juga dari segi pengarahan yang diberikan hakim. Terutama dalam penalarannya untuk sampai pada satu keputusan. Terkadang fungsi pengarahan ini juga disebut sebagai fungsi hukum yang mendetail.

7. Pengaturan kekuasaan pemerintah. Apabila pembangunan itu merupakan suatu kegiatan untuk melakukan perubahan-perubahan di dalam masyarakat, maka barang tentu dapat dimengerti, bahwa peranan pemeritah sebagai badan eksekutif menjadi menonjol. Dialah badan yang menjadi saluran bagi dilaksanakannya kebijakan pembangunan itu ke dalam tindakan-tindakan yang nyata. Sebagaimana di atas telah disinggung maka kegiatan-kegiatan yang meningkat itu menimbulkan risiko yang mengganggu kepentingan perorangan anggota masyarakat. Dengan demikian untuk tidak menghasilkan buah yang berlawanan dengan yang dikehendaki oleh pembangunan itu sendiri, tindakantindakan atau langkah-langkah pemerintah itu sendiri perlu diatur 
sehingga tertib. Oleh karena penertiban atau pengaturan di sini menyangkut tindakan-tindakan badan-badan pemerintah, maka peranan hukum administrasi menjadi penting.

Beberapa point peranan yang telah disebutkan di atas pada intinya berpangkal pada fungsi hukum selain sebagai sarana social control juga sebagai sarana social engenering. Artinya, pendayagunaan hukum sebagai kerangka landasan pembangunan tidak cukup menjadikannya sekedar bersifat reaksioner dan imperatif terhadap pembangunan, tetapi juga harus didayagunakan untuk bersifat proaktif terhadap pembangunan, yang mendorong dan merekayasa kualitas sumber daya manusia dan lingkungan untuk mempercepat proses tercapainya cita-cita pembangunan, yaitu manusia Indonesia yang berkualitas serta masyarakat adil dan makmur merata materiil dan spirituil.

Dalam kerangka ițu sangat perlu dipertimbangkan untuk pula melakukan setidaknya tiga hal. Pertama, mencabut semua undang-undang yang tidak sesuai dengan landasan idiil Pancasila, landasan konstitusional UUD 1945 dan landasan hak asási manusia seperti UU No. 1/PNPS/1963, ketentuan mengenai haatzai artikelen dan sebagainya yang jelas-jelas secara historis tidak relevan dengan makna hakiki kemerdekaan serta mengungkung kebebasan dan sumber daya manusia untuk berkembang. Kedua, mengurangi sedemikian rupa pembentukan model perundang-undangan yang berorientasi pada prinsip hukum represif, dan Ketiga, membuat RUU regulatif yang mengandung pemenuhan hak-hak asasi manusia serta mempercepat pemenuhan aturan peralihan pasal 2 sehingga aturan- aturan peninggalan kolonial dapat ditinggalkan.

Di luar harapan itu maka pendayagúnaan hukum nasional sebagai kerangka landasan pembangunan juga harus diserasikan dengan orientasi ke arah tinggal landas pembangunan.. Dalam hubungan ini Prof. Padmo Wahyono (alm) dalam makalahnya "Kesiapan Bidang. Hukum Dalam menyambut Kerangka Tinggal Landas Pembangunan", 1983 menyarankan beberapa kegiatan persiapan bidang hukum yaitu :

- disusun suatu perundang-undangan yang mengatur tentang pokok-pokok peraturan perundang-undangan yang memuat patokan-patokan baik mengenai materi maupun teknik perundangan-undangan dan sudah barang tentu mengenai bentuk/jenis peraturan perundang-undangan.

- disusun suatu program legislatif nasional dengan mission utama menggantikan peraturan perundangundangan kolonial di samping peraturan perundang-undangan yang harus memperlancar pembangunan.

- secara kesinambungan diadakan pemikiran yang tuntas mengenai asas dan kerangka sistem hukúm nasional, dalam menyambut tahap tinggal landas pembangungan.

- diadakan pemikiran yang berkesinambungan tentang dasar-dasar - pengaturan daripada hal-hal yang diinstruksikan oleh UUD 1945 yang meliputi antara lain :

- pelaksanaan fungsi legislatif;

- pelaksanaan fungsi eksekutif / pembangunan;

- pelaksanaan fungsi kehakiman;

- pelaksanaan fungsi pengawasan, polisional; 
- pelaksanaan fungsi keuangan dan pengawasan keuangan negara;

- pelaksanaan fungsi kepenasehatan, perencanaan;

- pelaksanaan fungsi hubungan luar negeri;

- ' tatanan pemerintah daerah;'

- t tatanan hidup keagamaan;

- tatanan hak warganegara dan kedudukan (hak kemanusiaan); :

- tatanan berkelompok dan menyatakan pendapat;

- tatanan pertahanan negara;

- tatanan pendidikan kebudayaan;

- tatanan kesejahteraan sosial;

- tatanan perekonomian;

- tatanan persatuan dan pengeluaran;

Disamping luas tentang pengetahuannya mengenai hukum, baik dalam rangka penyuluhan hukum, bantuan hukum, pendidikan hukum formal maupun non formal, baik yang menyangkut aspek sikap dalam rangka pembinaan kesadaran hukum, aspek pengetahuan dalam rangka pembinaan keterampilan mengemukakan dan memanfaatkan hukum serta kegiatan meningkatkan keterampilan dan kewibawaan para pembentuk, pengayom dan pemikir hukum secara terpadu baik dalam hubungannya dengan medan juang operasional maupun dalam hubungarinya dengan medan juang pemikiran.

Aspek-aspek pemikiran Prof. Padmowahyono (alm) di atas jelas menggariskan pedoman dasar pendayagunaan hukum dalam rangka persiapan tinggal landas pembangunan yang tidak sekedar membentuk perangkat normatif sebagai sarana instrumental (control sosial), tetapi juga mensyaratkan pendayagunaan hukum sebagai sarana social engenering untuk mempersiapkan sumber daya manusia yang siap memasuki masa tinggal landas pembangunan.**

\section{REFERENSI}

Abdurahman Saleh, SH. "Aneka Masalah Hukum dan Pembangunan", Alumni, tahun.1979. GBHN

Mulyana W. Kusumah, SH. "Perspektif, Teori dan Kebijaksanaan Hukum", Rajawali, Th. 1986.

------., "Peranan dan Pendayagunaan Hukum Dalam Pembangunan", Alumni, 1984.

Padmo Wahyono, "Persiapan Bidang Hukum Dalam Menyambut Kerangka Tinggal Landas Pembangunan" (Makalah), 1983.

'Satjipto Rahardjo, "Hukum dan Masyarakat". Angkasa, Th. 1980. 